\title{
EFFECT OF HUMAN DEVELOPMENT INDEX ON GDP FOR DEVELOPING COUNTRIES: A PANEL DATA ANALYSIS
}

DOI: 10.17261/Pressacademia.2020.1307

JEFA- V.7-ISS.4-2020(4) -p.338-345

\section{Tuba Gulcemal}

Sivas Cumhuriyet University, Faculty of Tourism, Sivas, Turkey. tgulcemal@cumhuriyet.edu.tr, ORCID 0000-0003-4806-8568

Date Received: September 20, 2020

Date Accepted: November 19, 2020

To cite this document

Gulcemal, Tuba (2020). Effect of human development index on GDP for developing countries: a panel data anaysis. Journal of Economics, Finance and Accounting (JEFA), V.7(4), p.338-345.

Permanent link to this document: http://doi.org/10.17261/Pressacademia.2020.1307

Copyright: Published by PressAcademia and limited licensed re-use rights only.

\begin{abstract}
Purpose - The main purpose of this study is to test the effect of human and physical capital on GDP. The study aims to realize this by means of using gross fixed capital formation as physical capital indicator and education expenditures, life expectancy at birth as human capital indicators by analyzing the data of the 16 developing countries

Methodology - This study aims to determine the long-run impact of physical and human capital on GDP by using the panel data set of 16 developing countries over the period 1990-2018. In the established model, growth (GDP) is the dependent variable, Human Development Index (HDI), Inflation (INF), Government Capital, ODA proxied as official development assistant, Investment (INV) proxied as foreign direct investment and Labour (LAB) as independent and control variables are included. Random and Fixed effects estimation techniques are employed to analyse and assess the significance relationship between economic growth and human development index.

Findings- According to test results, human development supports economic growth. It can be noticed that inflation is significant and have a negative relationship with economic growth and development for our sample and period. It can be recorded that Labour (LAB) has a significant and is positively related to economic growth. Goverment capital (GC) is seen to be positively related to growth (GDP) and also significant.

Conclusion- The key findings and results of the study suggested the existence of a positive and significant impact of human development on economic growth and development in developing countries. The study employed Human Development Index as the main variable of interest with GDP considered as the dependent variable with inflation, gross capital, foreign direct investment and labour as control variables. The study also came out with the findings that labour also have a positive and significant relationship with growth as recorded by most researchers. More governmental efforts should be placed on the development of the human capital. For the area of life expectancy, governments should provide good and better health care policies and facilities, health insurance for every citizen.
\end{abstract}

Keywords: Human development index, economic growth, developing countries, random effect, fixed effect. JEL Codes: 0150, 0160, 047

\section{INTRODUCTION}

This paper emphasizes on the relationship between human development and economic growth focused on developing countries. The intention here is to understand this impact and relationship by estimating the impact.

Human capital is a value invested in people (employees), primarily through education and health care, to create knowledge, skills and work capabilities. The role of human resources in the development of enterprises and national economies has recently increased and so have the attempts of their presentation and measurement of their impact on growth and development. The Human Development Index has increasingly been used as an indicator of human development (Aksentijević and Ježić, 2017:120).

The Human Development Index (HDI) is a summary measure of average achievement in key dimensions of human development: a long and healthy life, being knowledgeable and have a decent standard of living. The human development index (HDI), developed by the United Nations Development Programme (UNDP). As indicated by the UNDP, an indicator to quantify the accomplishment of human development is the human development index (HDI) (Appiah, Amoasi and Frowne,2019:102). The HDI is the geometric mean of normalized indices for each of the three dimensions. The health 
dimension is assessed by life expectancy at birth, the education dimension is measured by mean of years of schooling for adults aged 25 years and more and expected years of schooling for children of school entering age. The standard of living dimension is measured by gross national income per capita. The HDI uses the logarithm of income, to reflect the diminishing importance of income with increasing GNI (http://hdr.undp.org/en/content/human-development-index-hdi). This composite index measuring average achievement in three basic dimensions of human development $-\mathrm{a}$ long and healthy life, knowledge and a decent standard of living. The HDI is the geometric mean of normalized indices for each of the three dimensions. The greatest change in the calculation of the Human Development Index has occured in the category of the population's education. While in 2010 the calculation of the Human Development Index included adult literacy and enrollment in education, since 2010, the Education Index has consisted of mean and expected years of schooling (Aksentijević and Ježić, 2017:115). The HDI is the geometric mean of the three dimensional indices:

$\mathrm{HDI}=\sqrt[3]{I \text { (health).I (education).I (income }}$

\section{Figure 1: Human Development Index}

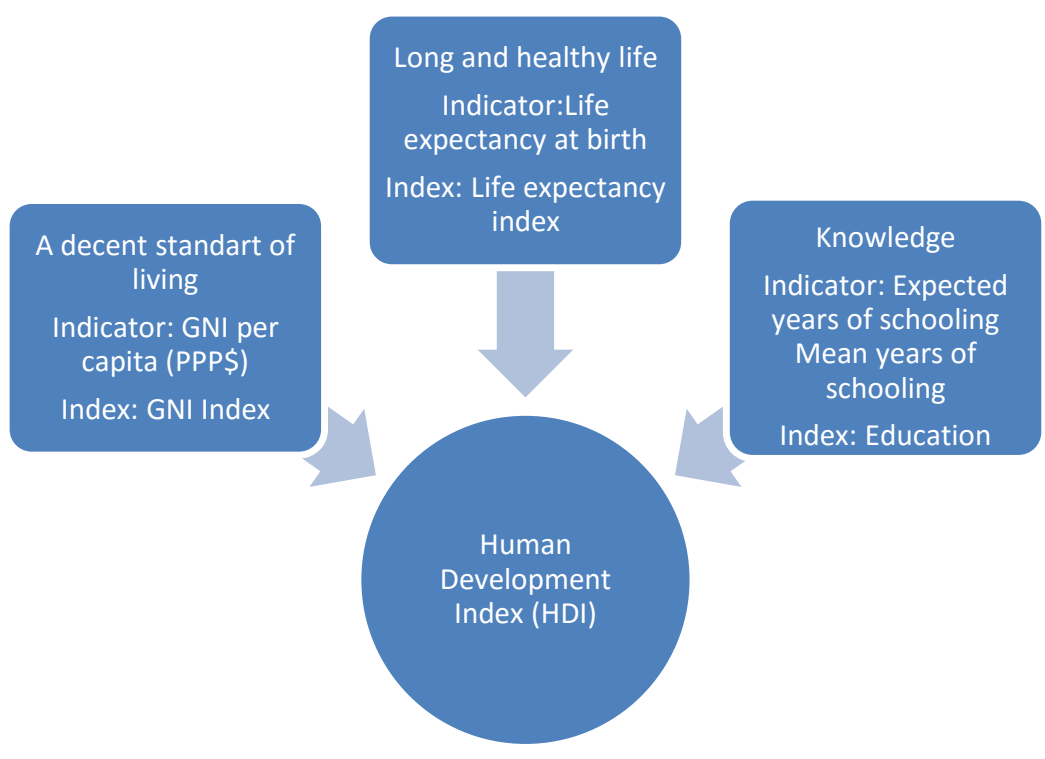

Source: http://hdr.undp.org/en/content/human-development-index-hdi

Hence the value of HDI for each country in each dimension must fall between zero and one (inclusive). The value reflects the proportion achieved in the aggregate for each country, with values closer to one reflecting higher achievement levels. Conversely, the proportionate deficiency or shortfall of a country in a particular dimension is equivalent to (1-HDI). The maximum potential for each country has been standardized-as has the minimum potential-and consequently achievement has been normalized on the 0-1 scale (Hicks, 1997:1286).

Since 2010, new criteria for ranking of the countries have been applied taking into account the Human Development Index. All countries are classified into four groups, so that each of the groups includes $1 / 4$ of the observed countries. In 2014 and 2015, countries were categorised into four groups according to the new methodology (http://hdr.undp.org/sites/default/files/hdr2015_technical_notes.pdf):

$>$ Very High HDI countries (0,800-1,000).

$>$ High HDI countries $(0,700-0,799)$.

$>$ Medium HDI countries (0,550-0,699).

$>$ Low HDI countries $(0-0,549)$. 
Tablo 1: Country Ranking according to HDI in 2019

\begin{tabular}{llllll}
\hline & Country & $\begin{array}{l}\text { Human } \\
\text { Development } \\
\text { Index }\end{array}$ & $\begin{array}{l}\text { Life expectancy } \\
\text { at birth (years) }\end{array}$ & $\begin{array}{l}\text { Expected } \\
\text { of schooling } \\
\text { (years) }\end{array}$ & $\begin{array}{l}\text { years } \\
\text { GrossNational } \\
\text { Income(GNI) } \\
\text { per capita PPP \$ }\end{array}$ \\
\hline 50 & Kazakhstan & 0.817 & 73.2 & 15.3 & 22,168 \\
52 & Bulgaria & 0.816 & 74.9 & 14.8 & 19,646 \\
52 & Montenegro & 0.816 & 76.8 & 15.0 & 17,511 \\
52 & Romania & 0.816 & 75.9 & 14.3 & 23,906 \\
55 & Palau & 0.814 & 73.7 & 15.6 & 16,720 \\
56 & Barbados & 0.813 & 79.1 & 15.2 & 15,912 \\
57 & Kuwait & 0.808 & 75.4 & 13.8 & 71,164 \\
57 & Uruguay & 0.808 & 77.8 & 16.3 & 19,435 \\
59 & Turkey & 0.806 & 77.4 & 16.4 & 24.905 \\
60 & Bahamas & 0.805 & 73.8 & 12.8 & 28,395 \\
\hline \hline
\end{tabular}

Source:http://hdr.undp.org/en/content/2019-human-development-index-ranking

The remainder of the paper is structured as follows: Section-II reviews a brief related empirical literature. The descriptions of variables, data source and empirical model are analyzed in Section-III. Section-IV discusses empirical techniques used in the analysis and results. Section-V presents concluding remarks and policy implications along with future directions.

\section{LITERATURE REVIEW}

Many authors like Balcı and Özcan (2019) studied the relationship between economic growth and human development. The relationship between Human Development Index (HDI) and economic growth were analyzed using panel data of OIC countries (The Organization of Islamic Cooperation) between 2005-2017. The study analyzed 54 OIC member countries. Results of the paper shows that there is a significant relationship between economic growth and human development in OIC countries.

It is widely accepted that economic growth makes a positive contribution to human development. According to Ranis (2004) greater freedom and capabilities improved economic performance and human development had an important effect on economic growth. To the extent that increased incomes increase the range of choices and capabilities enjoyed by households and governments, economic growth enhanced human development. While changes in human capital and labour quality matter most for endogenous growth, it is the level of human development that determines a nation's sustainable growth path. That article analyzed two way linkages relationship.

Isola and Alani (2012) on the other hand examined the relationship between human capital development and economic growth employing time series econometric technique and a Solow Augmented model. In the study, the dependent variables is measured by GDP per growth while the independent variables include growth rate of labour, growth rate of capital, Structural Adjustment Programme and the human capital output method - Life literacy rate and Adult literacy rate. In the study conducted by George and Ogunyomi (2019) in Nigeria, also concluded that human capital has a positive relationship with economic growth. The study found that human capital development, curriculum development, inflation rate and GINI index were the missing link variables in achieving long run economic growth within 1985-2016 in Nigeria.

Also, the study found bidirectional causality between human capital development and economic growth using income measurement approach. The argument was supported by Howitt and Aghion (1998) who noted that an increase in research and development (which is a by-product of human capital development) boost long term economic growth prospects. Adeyemi and Ogunsola (2016), education (one of the determinants of human capital development) equips workers with the competencies, skills and knowledge which are necessary not only for a country's development but also for sustainable economic growth (Tsaurai ,2018:133).

Singh (2012) also studied the role of financial globalization in influencing human development of emerging economies and emphasized the connection between globalization and human development. This study established that financial globalization improves development and growth process but considering poverty as averse to human development. According to findings, financial globalization can play no role in improving human development. 
Agarwal (2006) emphasized in his work paper about higher education in India, the need for greater adaptability in the higher education system so that it continues to provide the needed skills and trained workforce to the economy as it integrates with the world economy. Education as well as training improves the skills and capabilities of individuals and making them the centre of a country's economic development. Countries focusing on human capital formation in a few years are achieving higher growth course in GDP, including per capita income. As indicated by the new worldview, referenced by Mihaela and Georgiana (2015) human development can be viewed as a process of expanding the genuine opportunities delighted in by the general population.

Basu and Guariglia (2007) also investigated the association among human capital inequality, foreign direct investment (FDI) and economic growth by using panel data of 119 developing countries for the period of 1970-1999. The results of the study prove that FDI has a positive and significant impact on human inequality and economic growth in developing economies. And also Arcelus, Sharma, and Srinivasan (2005) scrutinize the effect of FDI on human development using the HDI scores for both middle- and low-income countries. For the sample period of 1975-1999, they find that FDI has positive and significant impact on human development for both groups of countries. Bjørnstad and Skjerpen (2006) have examined the linkages between globalization and income inequality in the Norwegian economy. The study utilized data from the period of 1972 to 1997 and found that foreign direct investment increases unemployment which in result increases income inequality and affect human development.

On the other hand, Reyes and Useche analyzed (2018) the performance and the relationship between competitiveness, real gross domestic product (GDP) growth and human development in 20 countries of the Latin America and Caribbean region during the 2006-2015 period. At the individual country level, no statistically significant relationship between economic growth and human development was detected. Acemoğlu and Johnson (2014) assessed controlling for potential lagged effects of initial life expectancy using data from 1900, employing a nonlinear estimator and using information from microeconomic estimates on the effects of improving health. And found no evidence for a positive effect of life expectancy on GDP per capita in this important historical episode.

\section{DATA AND METHODOLOGY}

According to the model used in analysis; where economic growth proxied as GDP as the dependent variable, Human Development Index (HDI), consumer price index proxied as Inflation (INF), Government Capital formation measured in \% of GDP as proxied as GC, official development assistant proxied as ODA (measured in current \$) as explanatory variables and foreign direct investment proxied as INV (measured as \% of GDP) and Labour (LAB) as control variables. In this study, selecting the variables in the growth model adopted by Barro et al., 1995; Solow, 1956, used Random and Fixed effects estimations.

Growth $(G D P)_{i t}=a+\beta_{1} I N F_{i t}+\beta_{2} G C_{i t}+\beta_{3} H D I_{i t}+\beta_{4} O D A_{i t}+\beta_{5} I N V_{i t}+\beta_{6} L A B_{i t}+e_{i t}$

The data set and variables used in this study for 1990-2018 period and contains 16 developing countries; Czech Republic, Egypt, Hungary, Poland, Russia, Saudi Arabia, South Africa, Turkey, China, United Arap Emirates, Argentina, Brazil, Mexico, Colombia, Peru and Chile. For these countries data set is accessible for all variables employed in this study so our data set is a balanced data. Qatar for example removed from dataset because official development assistant variable couln't be accesed for 2005-2018 years. The variable of human development index (HDI), developed by the United Nations Development Programme (UNDP) for the countries calculated between 1990-2018 years (this is our limitation) and obtained from http://hdr.undp.org, United Nations Development Programme's website. This composite index measuring average achievement in three basic dimensions of human development-a long and healthy life, knowledge and a decent standard of living. The other variables in this study obtained from World bank development indicators and world bank database (https://data.worldbank.org). The table below contains information about variables used in analysis.

\section{Table 2: Summary of the Variables}

\begin{tabular}{|l|l|l|}
\hline Variables & Unit & Source \\
\hline $\begin{array}{l}\text { Growth- GDP sum of gross value added by all resident producers } \\
\text { in the economy plus any product taxes and minus any subsidies } \\
\text { not included in the value of the products. }\end{array}$ & Current \$ & World Bank Open Data \\
\hline $\begin{array}{l}\text { Human Development Index -HDI The scores for the three HDI } \\
\text { dimension indices are aggregated into a composite index using } \\
\text { geometric mean. }\end{array}$ & Percentage & Human Development Data \\
\hline $\begin{array}{l}\text { Inflation-INF (consumer price index) reflects changes in the cost } \\
\text { to the average consumer of acquiring a basket of goods and }\end{array}$ & Percentage & World Bank Open Data \\
\hline
\end{tabular}




\begin{tabular}{|l|l|l|}
\hline $\begin{array}{l}\text { services that may be fixed or changed at specified intervals, such } \\
\text { as yearly. }\end{array}$ & & \\
\hline $\begin{array}{l}\text { Government Capital- GC (\%of GDP) consists of outlays on } \\
\text { additions to the fixed assets of the economy plus net changes in } \\
\text { the level of inventories. }\end{array}$ & Percentage & World Bank Open Data \\
\hline $\begin{array}{l}\text { Offical Development Assistance- ODA (net received consists of } \\
\text { disbursements of loans made on concessional terms (net of } \\
\text { repayments of principal) and grants by official) }\end{array}$ & Current \$ & World Bank Open Data \\
\hline Investment-INV (foreign direct investment \% GDP) & Percentage & World Bank Open Data \\
\hline $\begin{array}{l}\text { Labour- LAB (Labor force comprises people ages 15 and older } \\
\text { who supply labor for the production of goods and services during } \\
\text { a specified period) }\end{array}$ & Thousands & World Bank Open Data \\
\hline
\end{tabular}

At first, a unit root estimation is conducted to determine the stationarity of the data by using the Im, Pesaran and Shin procedure in the estimation. Secondly, both Random and Fixed effects estimation techniques are employed to analyse and assess the significance relationship between economic growth and human development. Finally, Hausman Test is conducted to choose the appropriate method for the model.

\section{FINDINGS AND DISCUSSIONS}

Im, Pesaran, and Shin (2003)'s panel unit root test sequentially on progressively smaller fractions of the original data set, where the reduction is carried out by dropping series for which there is evidence of stationarity, signalled by low individual t-statistics (Pesaran, 2011:4). The IPS (Im-Pesaran-Shin) test takes a different approach from the other unit root tests in that it views the panel data regression as a system of $\mathrm{N}$ individual regressions and is based on the combination of independent Dickey-Fuller tests for these $\mathrm{N}$ regressions. Besides allowing heteroskedasticity, serial correlation, and non-normality, this test also allows for heterogeneity of trends and of the lag coefficient under the alternative hypothesis of no unit root (Hall and Mairesse, 2002:5).

Table 3 shows the results of the IPS test for unit roots on the data, as the null hypothesis of IPS test is" all panels contain unit roots" it was not rejected at Level with or without time trend. The hypothesis of all panels having unit root was rejected at the 1st Difference of the panels with or without time trends. All the variables which were used in the study found to be stationary at first difference according to $\rho$-values.

Table 3: Unit Root Estimation Test Results

\begin{tabular}{|c|c|c|c|c|c|c|c|c|}
\hline \multirow{2}{*}{$\begin{array}{l}\text { Im Pesaran- } \\
\text { Shin Unit } \\
\text { Root Test } \\
\text { Variables } \\
\end{array}$} & \multicolumn{2}{|c|}{$\begin{array}{l}\text { Level Panel: Not } \\
\text { Included Time Trend }\end{array}$} & \multicolumn{2}{|c|}{$\begin{array}{l}\text { Level Panel: Included } \\
\text { Time Trend }\end{array}$} & \multicolumn{2}{|c|}{$\begin{array}{l}\text { 1st Difference Panel: } \\
\text { Not Included Time } \\
\text { Trend }\end{array}$} & \multicolumn{2}{|c|}{$\begin{array}{l}\text { 1st Difference Panel: } \\
\text { Included Time Trend }\end{array}$} \\
\hline & T.statistic & p-value & T.statistic & p-value & T.statistic & $p$ value & T.statistic & $p$ value \\
\hline GDP & 4.8561 & 1.0000 & 0.5900 & 0.7224 & -7.830 & $0.000 * * *$ & -5.589 & $0.000 * * *$ \\
\hline INF & 6.7518 & 1.0000 & 2.9517 & 0.9984 & -2.028 & $0.0200 * *$ & -1.952 & $0.0254 * *$ \\
\hline $\mathrm{GC}$ & -4.238 & $0.0000 * * *$ & -2.706 & $0.0034 * * *$ & -11.46 & $0.0000 * * *$ & -9.085 & $0.0000 * * *$ \\
\hline HDI & 0.9044 & 0.8171 & 1.2448 & 0.8934 & -7.216 & $0.0000 * * *$ & -6.740 & $0.0000 * * *$ \\
\hline ODA & -0.032 & 0.4871 & -2.183 & $0.0145^{* *}$ & -12.43 & $0.0000 * * *$ & -9.764 & $0.0000 * * *$ \\
\hline INV & -5.104 & $0.0000 * * *$ & -3.056 & $0.0011 * * *$ & -13.86 & $0.0000 * * *$ & -11.92 & $0.0000 * * *$ \\
\hline LAB & 3.4443 & 0.9997 & 0.4036 & 0.6568 & -5.413 & $0.0000 * * *$ & -4.814 & $0.0000 * * *$ \\
\hline
\end{tabular}

*** Significant at the $1 \%$ level, ** Significant at the $5 \%$ level, * Significant at the $10 \%$ level.

From table 4, it is recorded that human development has a significant effect and positively related to economic growth in the countries under study at a statistically significant value of $1 \%$ level. The estimated coefficient for Human Development (HDI) in equation is 5.39e+12; a 1-unit increase in Human Development (HDI) in developing countries would increase growth 5.39 unit by when all variables are held constant. 
Official development assistant (ODA) and foreign direct investment (INV) series are detected to be insignificant for developing countries. It can be recorded that INV has a non-significant position and negatively related to growth. Labour force (LAB), is defined as the currently active population within a country at a particular point in time and comprises of all persons who satisfy the criteria for inclusion amongst the employed. From the regression results from Table 4, it can be recorded that Labour (LAB) has a significant and is positively related to economic growth with probability value at $1 \%$ significant level (Khan, 2007); Manh, Dao, and Van Ngoc (2014) hypothesised that labour (Lab) has a positive impact on economic growth and this supports the findings. Herman (2011) argue the presence of a low employment elasticity of economic growth in EU, yet this has significant contrasts starting with one nation then onto the next. It can be noticed that inflation is significant and have a negative relationship with economic growth and development at a significant value of $1 \%$. These results and findings consistent with that of Barro (2013), Gokal and Hanif (2004), Pollin and Zhu, (2006), Andrés and Hernando (1997).

From table below, goverment capital (GC) is seen to be positively related to growth (GDP) and significant. Levine and Renelt (1992) recorded that capital has a positive relationship and significant on economic growth. In the same way (Blomstrom, Lipsey and Zejan, 1996; Kendrick, 1993) confirmed this result in their studies. Many studies and literatures proposes that human development supports economic growth. Studies from Ghosh (2006) and Saksena and Deb (2016) supports the results and findings of this study.

Table 4: Regression Statistics Dependent Variable: Growth (GDP Current USD)

\begin{tabular}{|c|c|c|}
\hline Variables & Fixed Effects & Random Effects \\
\hline INF & $\begin{array}{l}-4.07 e+09 * * * \\
(1.28 e+09)\end{array}$ & $\begin{array}{l}-3.33 e+08 \\
(1.32 e+09)\end{array}$ \\
\hline GC & $\begin{array}{l}3.71 \mathrm{e}+10 * * * \\
(1.16 \mathrm{e}+10)\end{array}$ & $\begin{array}{l}1.25 e+10 \\
(1.31 e+10)\end{array}$ \\
\hline HDI & $\begin{array}{l}5.39 \mathrm{e}+12^{* * *} \\
(1.37 \mathrm{e}+12) \\
\end{array}$ & $\begin{array}{l}7.51 \mathrm{e}+12 * * * \\
(1.01 \mathrm{e}+12)\end{array}$ \\
\hline ODA & $\begin{array}{l}2.321961 \\
(1.979774) \\
\end{array}$ & $\begin{array}{l}-4.451128^{* *} \\
(2.250678) \\
\end{array}$ \\
\hline INV & $\begin{array}{l}-1.06 e+10 \\
(6.97 e+09)\end{array}$ & $\begin{array}{l}-1.63 e+10 * \\
(8.94 e+09) \\
\end{array}$ \\
\hline LAB & $\begin{array}{l}56524.4^{* * *} \\
(3632.706) \\
\end{array}$ & $\begin{array}{l}6725.782^{* * *} \\
(558.3286) \\
\end{array}$ \\
\hline CONS & $\begin{array}{l}-7.75 \mathrm{e}+12 * * * \\
(7.90 \mathrm{e}+11)\end{array}$ & $\begin{array}{l}-5.51 \mathrm{e}+12^{* * *} \\
(6.43 \mathrm{e}+11)\end{array}$ \\
\hline PROB & 0.0000 & 0.0000 \\
\hline $\mathbf{R}^{2}$ & 0.5773 & 0.5404 \\
\hline
\end{tabular}

***Significant at the $1 \%$ level, ** Significant at the $5 \%$ level, * Significant at the $10 \%$ level. Standard errors are in parentheses

The estimation gives a summary of statistics for both Random and Fixed effects. The Hausman test (presented table 5) used to determine the appropriate model for estimations. Based on the result of the Hausman test it can be noted that the fixed effects model is appropriate for the model.

Table 5: Hausman Test Estimation

\begin{tabular}{|l|c|c|}
\hline Test Summary & Chi-Sq. Statistic & Prob.>chi2 \\
\hline Cross-section random & 125.47 & 0.0000 \\
\hline
\end{tabular}

From the above table 5 it tends to be noticed that there is a probability estimation of 0.0000 showing a significant value at a significant level of $1 \%$. The estimation tosses out the nearness of a relationship between the individual effects and the independent variables at the $1 \%$ level. Along these lines the null hypothes of the test "Difference in coefficients not systematic" can be rejected so it means the model for this examination is to be estimated with fixed effects estimations.

\section{CONCLUSION}

This study highlighted the significance of human development in achieving economic growth and development proxied as Gross Domestic Product (GDP) measured in current USD. The model shown a positive association, statistically significant 
between growth and human development as expected according to UNDP. The findings and results of the study suggest that more governmental efforts should be placed on the development of the human capital. For the area of life expectancy, governments should provide good and better health care policies and facilities for both the poor and the rich example like the introduction of health insurance by the government.

Unforeseen is the negative and insignificant connections between foreign direct investment (INV) and official development assistant (ODA) on Growth a possible reason being the heterogeneity of the study countries. And the negative coefficient of inflation variable lead to the conclusion that the findings and results are confirmed those of Pollin and Zhu, (2006), Barro (2013), Gokal and Hanif (2004), Andrés and Hernando (1997). However, we interpret the one of the reasons that human capital index become more efficient in respect of increasing the GDP in the developing countries as follows: increase in the life expectancy of these countries causes a positive contribution to the economy due to a longer time employment of the labor force rather than an increase in the financial burden of retirement and health expenditures made for older people, That means that the increase in the life expectancy of the developing countries leads to a positive contribution to economy. The model can be used as an alternative when conducting future studies on human development.

\section{REFERENCES}

Acemoglu, D. and Johnson, S. (2014). Disease and development: A reply to Bloom, Canning, and Fink. Journal of Political Economy, 122(6),1367-1375. https://doi.org/10.1086/677190

Adeyemi, P. A. and Ogunsola, J. A. (2016). The impact of human capital development on economic growth in Nigeria: ARDL approach. Journal Of Humanities and Social Science , 21(3), 1-7. DOI: 10.9790/0837-2103040107.

Agarwal, P. (2006). Higher Education in India. Indian Council for Research on International Economic Relations, Working Paper No. 180. http://www.icrier.org/pdf/ICRIER_WP180 Higher_Education in India_.pdf

Appiah, M., Amoasi, R. and Frowne, D. I. (2019). Human Development and Its Effects on Economic Growth and Development. International Research Journal of Business Studies, XII(02), 101 - 109. https://doi.org/10.21632/iribs.

Aksentijević, N.K. and Ježić, Z. (2017). Measuring the development of human resources with the usage of Human Development Index in selected CEE countries. In Wach, K., Knežević, B., \& Šimurina, N. (Eds.), Challenges for international business in Central and Eastern Europe (Przedsiębiorczość Międzynarodowa" vol. 3(1). Kraków: Cracow University of Economics, pp. 109-121.

Andres, J. and Hernando, I. (1997). Inflation and economic growth: some evidence for the OECD countries. Monetary Policy and the Inflation Process - BIS Conference Papers, n4, pp. 364-383.

Arcelus, F. J., Sharma, B. and Srinivasan, G. (2005). Foreign capital flows and the efficiency of the HDI dimensions. Global Economy Journal, 5(2), 1-12.

Balcı, E. and Özcan, S. (2019). İnsani gelişmişlik ve büyüme arasındaki ilişki: OıC ülkeleri üzerinde bir analiz. Sakarya Iktisat Dergisi, Cilt 8(3), ss. 222-235.

Barro, R.J. (2013). Inflation and economic growth. Annals of Economics and Finance. Vol. 14, pp. $121-144$. http://down.aefweb.net/AefArticles/aef140106Barro.pdf

Basu, P. and Guariglia, A. (2007). Foreign direct investment, inequality, and growth. Journal of Macroeconomics, $29(4), 824-839$.

Bjørnstad, R. and Skjerpen, T. (2006). Trade and inequality in wages and unemployment. Economic modelling, 23(1), 20-44.

Blomstrom, M., Lipsey, R. E. and Zejan, M. (1996). Is fixed investment the key to economic growth? The Quarterly Journal of Economics, Vol. 111, No. 1., pp. 269-276. Retrieved November 5, 2020, from http://www.jstor.org/stable/2946665

George, Emmanuel O. and Ogunyomi, O. O. (2019). Is there any Missing Link in the Nexus between Human Capital Development and Economic Growth in Developing Economies? Evidence from Nigeria. Acta Universitatis Danubius, Vol.15(1), pp. 117-133. ISSN: $2065-0175$.

Ghosh, M. (2006). Economic Growth and Human Development in Indian States. Economic and Political Weekly, Vol.41(30). https://www.epw.in/journal/2006/30/special-articles/economic-growth-and-human-development-indian-states.html

Gokal, V. and Hanif, S. (2004). Relationship Between Inflation and Economic Growth. Economic Department Reserve Bank of Fiji Working Paper No.4. https://www.rbf.gov.fj/relationship-between-inflation-and-economic-growth-by-vikesh-gokal-subrina-hanif-economics-groupdecember-2004/

Hall, B. H. and Mairesse, J. (2005). Testing for Unit Roots in Panel Data: An Exploration Using Real and Simulated Data. In D. Andrews \& J. Stock (Eds.), Identification and Inference for Econometric Models: Essays in Honor of Thomas Rothenberg (pp. 451-479). Cambridge: Cambridge University Press. doi:10.1017/CBO9780511614491.020.

Herman, E. (2011). The impact of economic growth process on employment in European Union countries. 14(42), 47-67. 
Hicks, D.A. (1997). The Inequality-Adjusted Human Development Index: A Constructive Proposal. World Development, Vol. 25, No. 8, pp. 1283-1298. http://hdr.undp.org/en/countries/profiles/TUR

Howitt, P. and Aghion, P. (1998). Capital Accumulation and Innovation as Complementary Factors in Long-Run Growth. Journal of Economic Growth, 3, 111-130. https://doi.org/10.1023/A:1009769717601

Isola, Wakeel A. and Alani, R. A. (2012). Human Capital Development and Economic Growth: Empirical Evidence from Nigeria. Asian Economic and Financial Review,2(7), 813-827.https://EconPapers.repec.org/RePEc:asi:aeafrj:2012:p:813-827

Kendrick, J. W. (1993). How much does capital explain? .Contributions to economic analysis, 214, pp.129.

Khan, A. R. (2007). Growth, employment and poverty: An analysis of the vital nexus based on some recent UNDP and ILO/ SIDA studies. DESA Working Paper No. 49, 1-45. https://www.un.org/esa/desa/papers/2007/wp49_2007.pdf

Levine, R. and Renelt, D. (1992). A Sensitivity Analysis of Cross-Country Growth Regressions. The American Economic Review, 82(4), 942-963. Retrieved November 5, 2020, from http://www.jstor.org/stable/2117352

Manh, P. H., Dao, H. T. T. and Van Ngoc, N. J. J. o. E. D. (2014). Relationship between economic growth and employment in Vietnam. JED, No. 222, 40-50.

Mihaela, N.D. and Georgiana, C.O. (2015). Correlations between human development and economic growth. Annals of the Constantin Brâncuşi University of Târgu Jiu Economy Series, Issue 1(1), 118-122.http://www.utgjiu.ro/revista/ec/pdf/201501.Volumul\%201/16_Neamtu,\%20Ciobanu.pdf

Pedroni, P. (2000). Fully modified OLS for heterogeneous cointegrated panels in Nonstationary Panels. Panel Cointegration and Dynamic Panels, H. B. Baltagi, (Ed.), vol. 15 of Advances in Econometrics, pp. 93-130

Pedroni, P. (2001). Purchasing power parity tests in cointegrated panels. Review of Economics and Statistics, vol. 83, no. 4, pp. $727-731$.

Pesaran, M. Hashem, (2011). On the Interpretation of Panel Unit Root Tests. http://www.econ.cam.ac.uk/peoplefiles/emeritus/mhp1/wp11/Interpretation-Panel-Unit-September-2011. pdf ,1-6.

Pollin, R. and Zhu, A. (2006). Inflation and Economic Growth: A Cross-Country Nonlinear Analysis. Journal of Post Keynesian Economics, 28, 593-614. http://dx.doi.org/10.2753/PKE0160-3477280404

Ranis, Gustav (2004). Human Development and Economic Growth. Center Discussion Paper No.887, Economic Growth Center, Yale University, 1-15. http://www.econ.yale.edu/ egcenter/research.htm

Reyes, G.E. and Useche, A.J. (2019). Competitiveness, economic growth and human development in Latin American and Caribbean countries 2006-2015: A performance and correlation analysis. Competitiveness Review, Vol. 29 No. 2, pp. 139-159. https://doi.org/10.1108/CR-112017-0085.

Saksena, S. and Deb, M. (2016). Transition pattern of Indian states across different categories of growth and development: Post economic liberalisation experience. Business and Economic Horizons, Vol.12, Issue3, pp.121-140. DOI: http://dx.doi.org/10.15208/beh.2016.10

Singh, A. (2012). Financial globalization and human development. Journal of Human Development and Capabilities, 13(1), 135-151.

Tsaurai, K. (2018). Is Human Capital Development a Channel Through Which Financial Development Influences Economic Growth? A Case of Emerging Markets. Euroeconomica, Issue 3(37), 130-139. ISSN: 1582-8859. http://hdr.undp.org/en/content/2019-human-developmentindex-ranking

Internet Sources

http://hdr.undp.org/en/content/human-development-index-hdi

http://hdr.undp.org/sites/default/files/hdr2015_technical_notes.pdf 